\title{
Coordinated plan to protect South China Sea
}

Hong Kong. An ambitious project to unite bitter political foes in mapping and modelling the environment of the South China Sea is being planned by the Hong Kong University of Science and Technology (HKUST). Scientists at the university say the plan is urgently required to prevent rapid development from overwhelming the sea's ecosystem.

Fifty marine scientists from five countries in the region backed the project at a meeting last December. Last month Professor Chen Jay-chung of HKUST and Gary Heinke, director of the university's institute of environmental studies, took the plan to officials of the United Nations Development Programme (UNDP) in New York. "They were very interested after we told them we had backing from Chinese and Vietnamese officials," says Chen. "They are waiting for our proposal."

Chen says the project would enable builders of a sewage plant in the Philippines, say, to work out the effects of possible sites and treatment systems on the sea as a whole. A similar model is already used in the similarly sized and enclosed Mediterranean Sea, he says.

The first stage of the project would collect data that already exist in various forms in the countries surrounding the sea, and then decide what other data were needed. Facilities and observation stations, including satellites and remote-sensing equipment, would be set up in a second stage.

The full project to set up the model, called Econet, would take up to 15 years and cost US $\$ 150$ million. Sponsorship will have to come from the governments involved and the United Nations.

The South China Sea's biodiversity, seabed and the flow patterns of its currents have not been extensively studied, and the sea is not heavily polluted. But that could change quickly, as it is almost fully enclosed by 10 rapidly developing countries.

Proponents of the plan concede that arranging collaboration between these countries will be a formidable political challenge. China, Taiwan, Malaysia, Brunei, the Philippines and Vietnam, for example, have rival claims to a small group of rocks called the Spratly Islands in the centre of the sea, mainly because of oil there.

UN officials were initially sceptical about the project because of the poor political relations between some of the partners. But senior officials in the environmental protection agencies of China and Vietnam are now supportive and the UNDP is interested. It suggested the two-phase approach, and asked for a detailed proposal by the end of the year. Funds for phase one could be available next summer if the project is accepted.

UNDP has also agreed to technical changes that will enable the proposal to be submitted directly by HKUST as a "regional project," rather than coming through the UK government, which has jurisdiction over Hong Kong only until next year.

The scientists behind the project are rac-

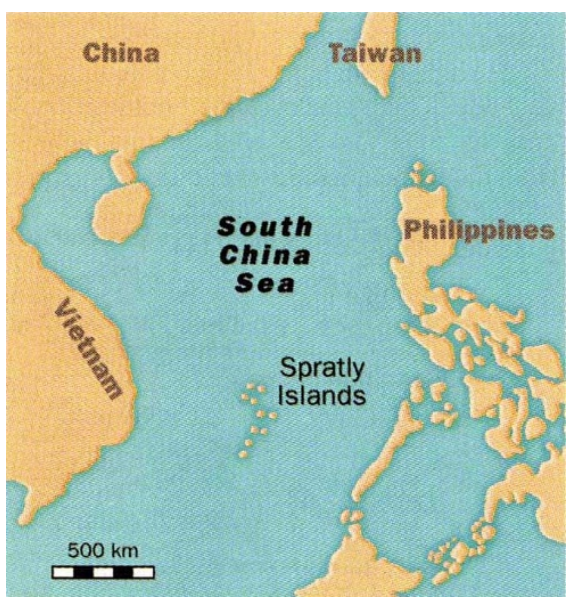

ing against time. Although there is awareness of the need to tackle pollution, action is not catching up with the breakneck speed of coastal development. Growing volumes of industrial waste and untreated domestic sewage are being pumped into the sea.

Development has already taken its toll on what were once large areas of mangroves. Their removal has left formerly protected

coastlines vulnerable to floods.

The project would look for hitherto unknown species in the mangroves, coral reefs and deep ocean mud, and aim to gather full knowledge of the area so that adverse effects of development could be assessed and avoided.

HKUST is drawing up a plan for a threeyear first phase, taking in the countries to the north of the sea - Hong Kong, China, Taiwan and Vietnam - and costing \$20 million. But there are already signs of friction between the would-be partners. A $\$ 3.6$ million biodiversity study started this year by the six claimants to the Spratlys is in trouble, as China and Vietnam each claims that it has found more species than the other.

Chen admits that China was instrumental in keeping the Philippines out of phase one. "And Vietnam doesn't want to have anything to do with China, they will only deal with us," he says.

He agrees that the players might be more interested in tracking down minerals rather than biological reserves: "There's always a danger of them trying to use the project to their own advantage, but we will have to be aware of that." Heinke concedes that the pace of development could outstrip the ability of the programme to protect the sea. "We have to do it sooner rather than later," he says.

Elisabeth Tacey

\section{Greens attack transgenic plant trials}

Munich. Biotechnology companies have conducted field trials of genetically engineered plants in Guatemala without informing local authorities and without taking appropriate biosafety measures, claims a report by Greenpeace, the environmental pressure group.

The pressure group calls on the governments of Guatemala and other Central American countries to declare a moratorium on such trials until mechanisms are put in place to regulate imports of genetically engineered organisms.

Greenpeace began an investigation last year into the activities of several companies with interests in genetically engineered crops. It alleges that the company Asgrow now a division of Seminis, based at Saticoy, California - conducted trials on transgenic tomatoes, squash and melons without notifying government authorities.

The company also sent genetically engineered seed to Guatemala from the United States by commercial courier service without marking the contents, Greenpeace says.

Greenpeace criticizes a trial on transgenic tomatoes which it says was conducted without systematic application of measures to prevent the accidental release of transgenic material into the environment. It alleges that greenhouse doors were often left open, for example. This raises the risk of cross-pollination, it argues, which would disturb the ecological balance by increasing the invasiveness and weed potential of the wild population. Tomatoes, like many other economically important crops, are indigenous to the area.

Greenpeace says the lack of legal regulation of these activities is a major problem. Although Asgrow did not transgress any particular law, the pressure group says that the company acted with "a lack of ethics", particularly by not informing authorities of the import and export of gene plasm. If there is damage to the environment, the Guatemala government will not be able to hold companies liable.

Greenpeace says that, as well as stopping field trials immediately, Guatemala should encourage the establishment of a framework agreement in Central America to define policies and standards for the use of genetically engineered products.

It also wants to ban the commercialization of products that present a risk to local flora and fauna. Individual countries should also adopt legislation to control the use of genetically engineered organisms in the region, Greenpeace says.

Alison Abbott 